\title{
高蔵寺ニュータゥン開発計画に及ぼした自然環境構造の影響 \\ Effects of the natural environmental structure on the Kozoji New Town development plan
}

\author{
篠沢 健太※ 宮城 俊作※※ 城地 園子※※※ \\ Kenta SHINOZAWA Shunsaku MIYAGI Sonoko JOCHI
}

\begin{abstract}
Kozoji New Town is one of the earliest large-scale residential developments in Japan. The plan was based on a land readjustment project which took into consideration natural disasters such as Typhoon Vera, large-scale developments such as the Aichi Canal, and social situations such as the advance of motorization. The master plan for Kozoji New Town changed over time while continuing the search for an ideal form of replotting design and solutions for problems with the transport plans in consideration of the natural environment of the site, but eventually a unique plan was realized incorporating the valley's large-scale main roads and pedestrian ways on the ridges branching out from the regional center which is concentrated in the one spot. In the process of changes in the master plan, the 'natural environment' of the site had considerable influence on the shedding of the neighborhood unit theory, the concentration and density of population and facilities in the centre and the pedestrian way connections. As Kozoji New Town made the local natural environment the fundamental structure of the new town, it became an opportunity for great changes in the attitudes towards planning spatial structures in subsequent new town planning, while continuing some development ideas from early New Town planning.
\end{abstract}

Keywords: Kozoji New Town, master plan, original landform, Landscape design, natural environmental structure キーワード：高蔵寺ニュータウン, マスタープラン, 原地形, ランドスケープデザイン, 地域環境構造

\section{1. はじめに}

高度経済成長時代に建設された大都市圈近郊のニュータウン (以下 NT と記す) は, 現在建替の時期を迎えている。少子高齢化 時代の現在, NT の課題は多岐に渡っており, 研究も増えつつある。 ランドスケーププランニング, デザイン分野においても，近年， 建替を機にかつてのNT計画およびNTの公園緑地計画を再認識し, 新たな理解を試みる研究がみられる。NT 開発時の空間計画と計画 基盤である自然環境の関係を読み解き，どのような計画思想に基 ゔいて計画がとりくまれたかを再認識し，今後，少子高齢化を迎 える地域における社会資本としてのNT のあり方や建替の方向性, 新たな可能性を検討する研究が進められつつある ${ }^{12)}$ 。

公園緑地計画の視点からみると, NT 開発の変遷は, 自然環境の 特性が NT の空間構造や都市機能と意図的に関連付けられ、内化さ れた港北 NT のグリーンマトリックスシステムにおいて, 1 つの頂 点を迎える ${ }^{34)}$ 。一方, 初期の NT 開発では技術的, 経済的制約や 地域の社会条件の影響を受けつつ, 自然環境が非意図的に空間構 造に組み込まれることがある ${ }^{5)}$ 。この自然環境の非意図的な組み 込みが意図的な計画へと成熟する過程で, NT 開発思想にどのよう な変化が生じたかについては未だ十分議論されてはいない。

本論ではNT 開発と自然環境の関係の変換点として高蔵寺 NT を 取り上げる ${ }^{6)}$ 。高蔵寺 NT の計画史については, すでに計画に主体 的に関わってきた都市計画家，高山英華によってとりまとめられ ている ${ }^{7)}$ 。また公園緑地計画に関しては村田 (1966) が報告し ${ }^{8)}$, 権ら（1994）は保存緑地に対する住民意識調査を行っている ${ }^{9)}$ 。 西山・石浦ら（1989）は 2 時点の住民意向の把握に基づいて名古 屋都市圈との関係から高蔵寺 NT の特質を把握した ${ }^{10)}$ 。こうした 住民意向や住夕替え意識など生活に即した調査研究の蓄積がある のに対して, 高蔵寺 NT と自然環境との関係を直接扱った既往研究 は限られる。山元 (2009) は, 地図資料を用いて高蔵寺 NT の造成 前後を比較し, 高蔵寺 NT の都市構造と地形の関係を $50 \mathrm{~m}$ メッシュ 単位で検証した ${ }^{11)}$ 。一般に知られている尾根・谷と歩専道・幹線
道路との対応にとどまらない，詳細な土地造成の存在を明らかに し，安全性への影響を指摘したが分析および住民への情報公開の 精度を課題としている。

前世紀末から立て続けに大きな災害に見舞われてきた我が国は, 現在，都市と自然環境との関わりについて，より繊細かつ真摰に 考えなければならない時期を迎えている。高蔵寺 NT も計画の発端 には都市への自然災害があった ${ }^{12)}$ 。1959（昭和 34）年, 名古屋市 域に多大な被害をもたらした伊勢湾台風は，低地域に住むことの 問題を浮き彫りにした。高蔵寺 NT のキャッチフレーズである「丘 に住もう」には，単に都市のスプロールを避けて郊外に居住する という意味のみでなく，自然災害を乗り越え「我々はどこに住む ベきか?」という切実な思いがある ${ }^{12)}$ 。高蔵寺 NT については,

これまで海外の事例や他の NT 開発との比較から, 新たな交通体系 や高密度な都市居住など, NT の機能から議論されてきた。しかし, 自然災害の経験に端を発し計画された高蔵寺NT は, 立地の自然環 境と取り組み，災害を克服すべく対処する試みの過程が，計画の 変遷として図面に示されていると考えられる。本事例研究はそこ に潜む計画意図，開発思想を読み解こうとするものである。また 近年，一見安定した現況地盤においても，造成の切盛境界や高盛 土部などで大規模な自然災害が発生し，開発前の原地形と開発と の関連が顕になっている。建替時期を迎えるNT の一つである高蔵 寺 NT において居住の安全面からもかつての計画を把握寸る必要 は高まっていると，筆者らは考える。

そこで本論では, (1)ランドスケープ計画・デザインの視野から 高蔵寺 NT マスタープランの変遷を把握し, (2)特に地形・地質など の自然環境の要因がマスタープランの変化にいかなる影響を与え たか?を明らかにした上で, (3NT 開発思想に生じた変化の検証を 試みる。

\section{2. 対象と手法 \\ （1）高蔵寺 NT の概要}

※工学院大学建築学部 ※奈良女子大学生活環境学部 ※※マルモ出版 
高蔵寺 NT は日本住宅公団（現：UR 都市機構）が初めて計画開 発した大規模 NT である。計画は，1951（昭和 36）年より開始さ れ，当初計画面積 847ha（のち 702ha), 計画人口は約 2 万戸, 8 〜 万人を想定して計画が進められた。用地の全てを買いあげる 一団地の開発やその後の新住宅市街地開発事業と異なり，土地区 画整理事業として整備したため，土地を所有していた多くの地権 者に対し換地を行う必要があった。また自家用車の普及が始まっ た時期にあたり，モータリゼーションを受け入れうるまちの構造 が要求された。

さらに当時，世界銀行の支援に基づく一大国家プロジェクト， 愛知用水が愛知県下で広域的に計画中であった。木曽川から渥美 半島にかけて愛知県を南北に縦断する愛知用水は，春日井市の高 蔵寺 NT 対象地の直下を通り，NT に水道用水を給水する一方で, 宅地や道路地盤高との調整が必要とされた。また対象地の一部に は自衛隊施設が含まれ，その移転計画が計画の前提となるなど， 大規模な土地利用の転換も想定されていた。

\section{（2）高蔵寺 NT 計画の特徵}

高蔵寺 NT 計画の特徵は，(1)サービス施設や機能を NT 中心施設 に集約するワン・センター・システム，(2)地形の起伏を用いた歩 車分離型の交通系統，(3)谷筋に配され，センターから放射状に地 域外に開放される幹線道路，(4)尾根上の歩行者動線に沿って機能 と高層住棟を集中して配したペデストリアン・ウエイの 4 点に大 きくまとめられる7)。こうした，NT の機能的構造を“骨太”に強 化していく NT 計画の思想は，その後の NT 開発に少なから影響 を及ぼしたと一般には考えられている。

\section{(3) 手法}

上記のような高蔵寺 NT 計画の変遷を, 自然環境との関係性から 読み解くことが本論の目的である。「高蔵寺ニュータウン計画」7) では，マスタープランは 1961 年〜1962 年の間に 4 つのフェーズ で変遷したと記されている $(6106,6111,6206,6212$ の各案)。最終 的な第 2 次マスタープラン（6401 案）は，その後さまざまな事情 により変遷して実施案 ${ }^{13)}$ に結実するが，本論では 6106〜6401 案 の 5 案を主な検討の対象とした。

自然環境との関係を把握し，相互に比較・検討寸るための手法 は極めて単純である。各マスタープラン案検討の際に描かれた土 地利用, 交通, 施設, 緑地など計画主題図を, 立地の地形的特徵 を表した基盤図にオーバーレイしそれぞれの計画の特徴，とくに その策定に影響を及ぼしたと思われる地形的特徵を, ランドスケ ープデザインの視点から再検証する。高蔵寺 NT 計画における立地 の地形的特徵を示寸基盤図として 6111 案策定時に作成された尾 根図を用いた ${ }^{14)}$ 。

上記の検討結果を NT 開発マスタープラン変遷の年表としてまと めた（図 1)。

\section{3. 高蔵寺 NT マスタープランの変遷と自然環境構造の関連 (1) 6106 案 計画単位としての住区}

高蔵寺 NT の最初のマスタープラン検討案である 6106 案では, マスタープラン策定と同時に土地区画整理事業における用途選定 と買収の指針が検討された。対象地内の「3 本の尾根に囲まれた 谷底低地」に 3 つ住区（L1 繁田川流域， L2 鎌茂川上流域・高森 山，L3鎌茂川下流域・自衛隊国有地）が設定された。まちの入口 と考えられていた JR 中央線より最も奥に位置する高森山周辺 L2 地区に地区センターを，その他 2 地区にサブセンターを配置する 計画であった。3 住区の大きさは谷底低地の広さによって異なっ ており，住区を規定する一定の空間単位は見られない。一方，住 区周辺，北の大谷川，東の鯎川に延びる尾根の先端に配置された 民有地（民間戸建住宅地）Lp は周囲の「既存集落と同じ規模」と して 500 戸の単位で設定された。
交通に関しては, 谷の出口を取付口として, 幹線道路 Ta が外部 と接続された。幹線道路は, これらの取付口から直線状に延び, 高森山麓に設定されたセンターへ，地形とは無関係にアプローチ している。この道路線形は尾根を削り, 谷を埋める大規模な造成 の必要性は予想されていたが, 計画構想段階の 6106 案では, 新た

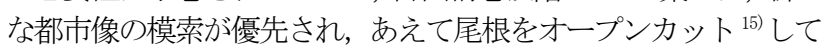

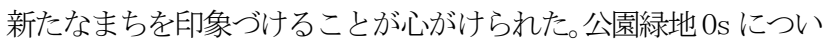
ては，対象地内の 4 つ山と自然公園をつなぐ体系的な公園緑地 配置が想定されている。

\section{（2）6111 案 ワン・センターへの移行と尾根地形の発見}

第一次マスタープランと呼ばれる 6111 案は, 土地区画整理事業 の基本条件の検討を課題の一つとし, 縮尺 1:10,000 で計画されて いる。土地購入が開始され，計画人口が 8 万人に決定された。

6106 案で各住区内に配置されていた公共機能を住区から分離,

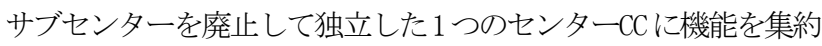
する形となった。センター地区は，「身洗川の谷筋」の「東西に狭 小で南北に長い瘦せ尾根」地形上に細長く伸びた形状で配置され た。このワン・センター・システムの形状は前 6106 案では「この 谷筋を見落としていたのだが…（中略）…ここにセンターをおく のがよいという結論に達した」 ${ }^{16)}$ と述べられているように，地形 的な制約の影響を強く受けている。一方「3 つの住区は主幹線道 路にぶらさがる形態」となったが，これは「開発プロセスと現在 自衛隊のしめている国有地が当面計画から外されても，一応機能

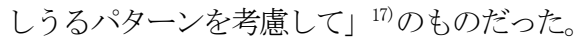

6111 案では, 歩車分離と都市構造のわかりや寸さの原則が確定 し, NT 主幹線を谷に, 緑道を尾根に配置されている。センターと 住区をつなぐ枝の部分はモール $\mathrm{m}$ と呼ばれる歩行者専用道路とな っている。日常生活の利用頻度が高い施設は住区内に分散させる が，その他の施設は「できる限り」センターに集中させる方針で あった。このモールと一部並行，一部独立して尾根上に緑道 $\mathrm{g}$ が 計画された。なお 6111 案の住区幹線道路 $\mathrm{Tb}$ は, 後の案に比べる とややいびつな環状となっている。尾根地形との対応が見られる とともに後に提案されるフォーク状の道路形状との関連も示唆さ れる。

\section{（3） 6206 案 オープンコミュニティ}

6206 案は, 6111 案の空間構成を継承しているが、その計画思想 の面では大きな変化が見られる。それまでは，住区を基本単位と する近隣住区論が計画思想の根底にあった。一方, 6206 案では, オープンコミュニティと呼ばれる, より流動的で開放的なコミュ ニティの考え方, 生活像が提唱された。住区がある単位にまとま るのでなく，相互に連携する「アソシエーションプラン」が基礎 となり, 空間単位（住区）から機能のネットワークへ計画思想が シフトした。この結果, 住区のまとまりは図示されつつも, 住区 とセンターを結ぶ, 特に尾根軸の歩行者動線の連続性, 機能強化 が進み, 最終的には住区に人口を均等に配分するのではなく，セ ンターから徒歩圈内に人口を集中させるよう, 住棟の高層高密化 が進められた。

歩行者動線は, モールからペデストリアン・デッキPd と呼び名 を変え, センターと住区を結ぶ機能的で高層高密な建築が並び立 つ歩行者空間が形作られた。一方, 緑道に沿って公園・教育施設 が配置され，「アソシエーションベルト Ab」が構想される。とく に東側尾根に形成された緑道と公共施設の帯は、後に港北 NT で実 現するグリーンマトリックスシステム（以下GMS と記す）との共 通性もみられる。なお谷沿いの幹線道路は前案を継承しているが, 住区内幹線道路のループ形状はより単純化されている。

\section{(4) 6212 案 ループから開放系へ}

土地区画整理事業の調整のため, 縮尺 $1: 6,000$ で検討された。 1962 年 8 月には, 日本住宅公団から NT に関連する 5 つの研究が 
外部委託され，開発の根拠が裏付けられた時期でもある。

この 6212 案で, 高蔵寺 NT マスタープランは住区クラスター型 から開放的な機能軸型へと大きく变化した。6106 案で対象地境界 部分の谷の出口にとりつけられた NT 幹線道路 Ta はセンターが配 置された尾根に沿う谷笳に配置され，接続する住区幹線道路 $\mathrm{Tb}$ は住区内でループ状に完結していた（6111，6206 案)。住区を囲 む尾根には歩行者専用道路である緑道が配置され，それに隣接し て学校や公園などの公共機能が集約されていた（6206 案）。この 外部に閉じた計画に対し，6212 案はNT・住区幹線道路を「開いて も何らさしつかえない」成) という判断から，環状の道路体系がセ ンターから周囲にY字状に拡がって外部一接続される「開放系」 の体系へ変化する。これは 6206 案で提唱されたオープンコミュニ ティ”の考え方にも後押しされた。

ペデストリアン・デッキと緑道も明確に機能分担されはじめる。 6206 案で緑道 g と並列していたペデストリアン・デッキPd は, センターへの徒歩圈での到達範囲をより拡張するため, より機能 的に尾根をつなぐ「ペデストリアン・ウエイ」として確立される。 6212 案で南北に伸長されたセンターから住区内一, 幹線道路に並 行して尾根上を伸長していく。一方，公団開発地と民有地の住区 境界の尾根に配置されていた緑道は，動線とは別の計画思想で議 論されるようになり，6206 案での「帯」から施設が外れ，幅の細 い外周道路へと変化した。公園緑地に関しては住区基幹公園とし て，誘致圈や規模が検討されるようになる ${ }^{19)}$ 。

\section{（5） 6401 案 第2次マスタープラン}

1964 年 1 月， 3 工区からなる第 2 次マスタープランが完成した (面積 847ha)。6401 案の特徵は(1)谷を結んでNT 主幹線道路を配置 し, 沿道の緑地と一体化する (6106, 6111 案)，(2)主幹線に沿った 尾根上にセンターを配置 (6111 案), 歩行者専用道路「ペデスト リアン・ウエイ」を住区内に枝状に伸ばし，到達しうる徒歩圈を 拡大寸る (6206, 6212 案), (3)ペデストリアン・ウエイに高密度な 中高層住宅地を配置するとともに諸都市機能を集中させる (6206, 6212 案), (4)高密度な土地利用の北側にオープンスペース を配置, 都市の背景を作る (6212 案), (5)一方, 「できる限り地形 の高い位置」でオープンスペースを確保するという点にあった。

6212 案でY字型の幹線道路が伸長するのに伴って変質した緑道 が中高層北側に沿ってペデストリアン・ウエイと並行して現れる。 同時に幹線道路に並行するペデストリアン・ウエイに直交し，そ の間をつなぐ形で歩行者専用道路と学校・公園緑地の帯状の配置 が一部，東側尾根筋の旧緑道部分に復活している。

\section{（6）実施へ一計画対象区域の切り離し—}

マスタープラン策定後の整備の過程や工事に関する詳細な議論 は本論では扱わない。但し，マスタープランと実施計画とは，高 蔵寺 NT の計画範囲で最も大きく異なっている。敷地南東側の国有 地は第 2 次マスタープランでは第 3 工区に位置づけられていたが, 国有地内の航空自衛隊高蔵寺弾薬庫の移転が中止となり，第 $3 工$ 区 145 ha が計画から除外された。対象地の約 2 割を占める範囲が 切り離されたその結果、高蔵寺 NT は北東から南西に延びるやや変 則的な形状となり，計画されていた Y 字型住区幹線道路の枝が 3 箇所から 2 箇所に減る結果となった。しかし対象地域の削減とい う大きな変更に対しても, 高蔵寺 NT の街としての機能に大きな問 題を生じなかったのは，住区，サブセンター，地区センターへ分 散した機能型の近隣住区論ではなく, 機能を 1 箇所のセンターに 集中しつつ、各住区とセンターとの機能的な繋がり，アプローチ を確実なものとしていた高蔵寺 NT マスタープランの空間計画が 強く影響しているものと思われる。

\section{6. 考察}

（1）地形に基づく空間単位一千里 NT から高蔵寺 NT へ一
高蔵寺 NT の開発計画においては, 計画マスタープランの変遷に 伴い，その計画思想も大きく変化していた。本論での議論の対象 である自然環境構造，特に地形が計画に及ぼした影響は大きい。 計画前後およびそれ以前の NT 開発と比較して, 地形が影響を及ぼ した点の 1 つに計画の「空間単位」がある。高蔵寺 NT より以前に 開発された千里 NT では, マスタープラン策定時に地形に基づいた 空間単位が参照されたことが指摘されている ${ }^{20)}$ 。千里 NT 開発当 初, 「一つ尾根を飛ばすと」適切な敷地が得られることが報告され, 近隣住区を意識した均質な単位空間が谷区画割図を下敷きに設定 されていた。高蔵寺 NT では当初は尾根に規定された 3 住区が設定 されたが, その際, 千里 NT の谷区画割図のような均質な単位空間 は設定されなかった。一部，外周の尾根斜面に配置された民有地 では，周辺集落規模に応じた住戸数の棈円が並ぶものの，立地の 自然環境に規定されてはいない。れは高蔵寺 NT の立地が長い尾 根が敷地南北に延び，単位を規定しづらいことに起因すると考え られる。また, 当時は人々の日常生活圈が近隣住区より広いこと などが議論されつつあり, NT 開発計画における計画単位としての 近隣住区論の単位性，拘束力が弱まった時期でもあった ${ }^{21)}$ 。

\section{（2）機能の軸一庋せ尾根地形の発見と流す尾根}

空間単位に束縛されず，一方で柔軟性のあるマスタープランが 求められるなか, 高蔵寺 NT は機能の連携を強く意識した計画へと 変化していった。その際, 立地の地形, 尾根・谷が, 機能の流れ, 軸に影響を及ぼしていた。谷筋については, 千里, 高蔵寺 NT とも 幹線道路が配置される点で共通しているが, 千里 NT では農業用水 の水利権が残るため池が計画に強い影響を及ぼした ${ }^{22)}$ のに対し, 高蔵寺 NT では対象地の水田面積割合は低く, また新たに愛知用水 が完成することもあり,ため池の NT 計画への制約は強くなかった と思われる。広域計画である愛知用水の影響は本論では明らかに できなかった。一方，尾根は，計画が大きく転換するセンター立 地とペデストリアン・ウエイの延長に大きく関与した。センター 配置のきっかけは, 6111 第 1 次マスタープランにおいて 6106 案 が「見落としていた」脆弱な尾根が発見されたことにあり，それ まで直線状に描かれていた NT 幹線道路が, この尾根に並行する谷 に沿って，緩やかに曲線を描くように配置される。一方センター から住区に至る歩行者動線は尾根筋に配置され，モール，ペデス トリアン・デッキ, ペデストリアン・ウエイと名前を変えつつ, 主要機能などを集積しつつ機能の軸を形成していく。最終的に充 実した機能の軸をもつ“骨太”のマスタープランが形成される過 程で, 地形を読み解き, 発見し, 利用, 適応していく変遷を確認 することができた。さらに微細な地形の取り扱いやランドスケー プデザインについては，別途検討が必要になる。

\section{（3）枝の切り落とし}

高蔵寺 NT において特筆すべき地形との関連の 3 点目は, 計画の 変更に対応できる計画の柔軟性にある。当初から南東側の国有地 の用地取得が課題であり，6111 案でもその問題が指摘されていた。 高蔵寺 NT 計画においては計画に柔軟性をもたせるためにも, 空間 単位に依拠する近隣住区は有利でなく, 機能を集約させるワン・ センター・システムと開放系の交通動線が必要だったとも言える。 センターを独立させ、空間構造から機能の連携へのシフトに拍車 をかけたのは高蔵寺 NT 敷地の地形であったが, 最終的にセンター から伸びた機能の枝を切り離しても, NT 全体に大きな破綻をもた らすことはなかったのも，機能を集中させうる断面形状をもち， さらに対象地を放射状に連結寸ることができた尾根地形の影響が 少なくない。

\section{(4) グリーンマトリックスヘ}

センター地区から延びる尾根に機能が集中し, 高層高密な住居 と機能を沿道に集中させたペデストリアン・デッキが形成される 一方で，6206 案では高蔵寺 NT 東側の尾根筋に緑道と公共施設の 


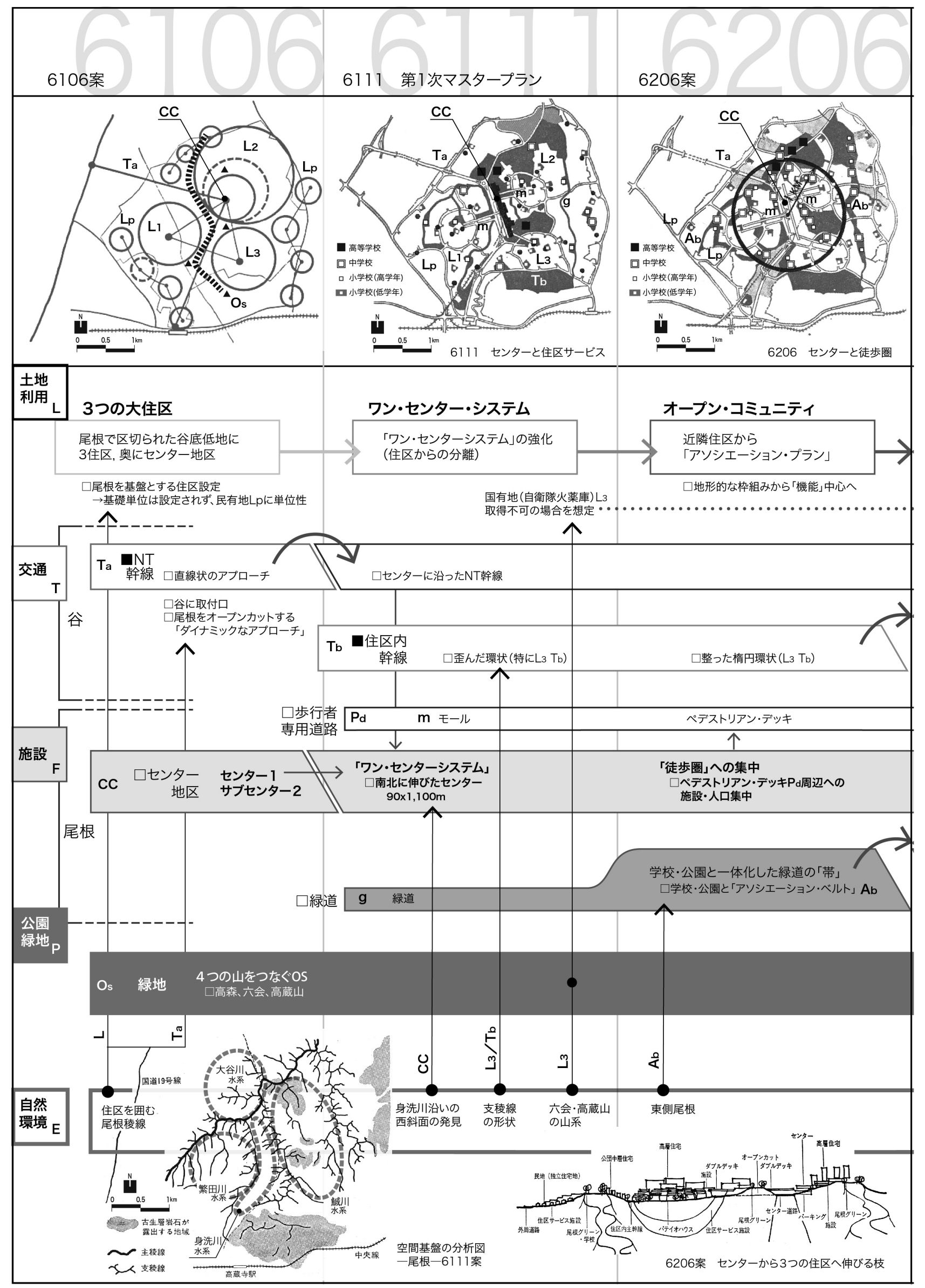

図 1 自然環境の影響から見た高蔵寺ニュータウン開発計画の経緯 


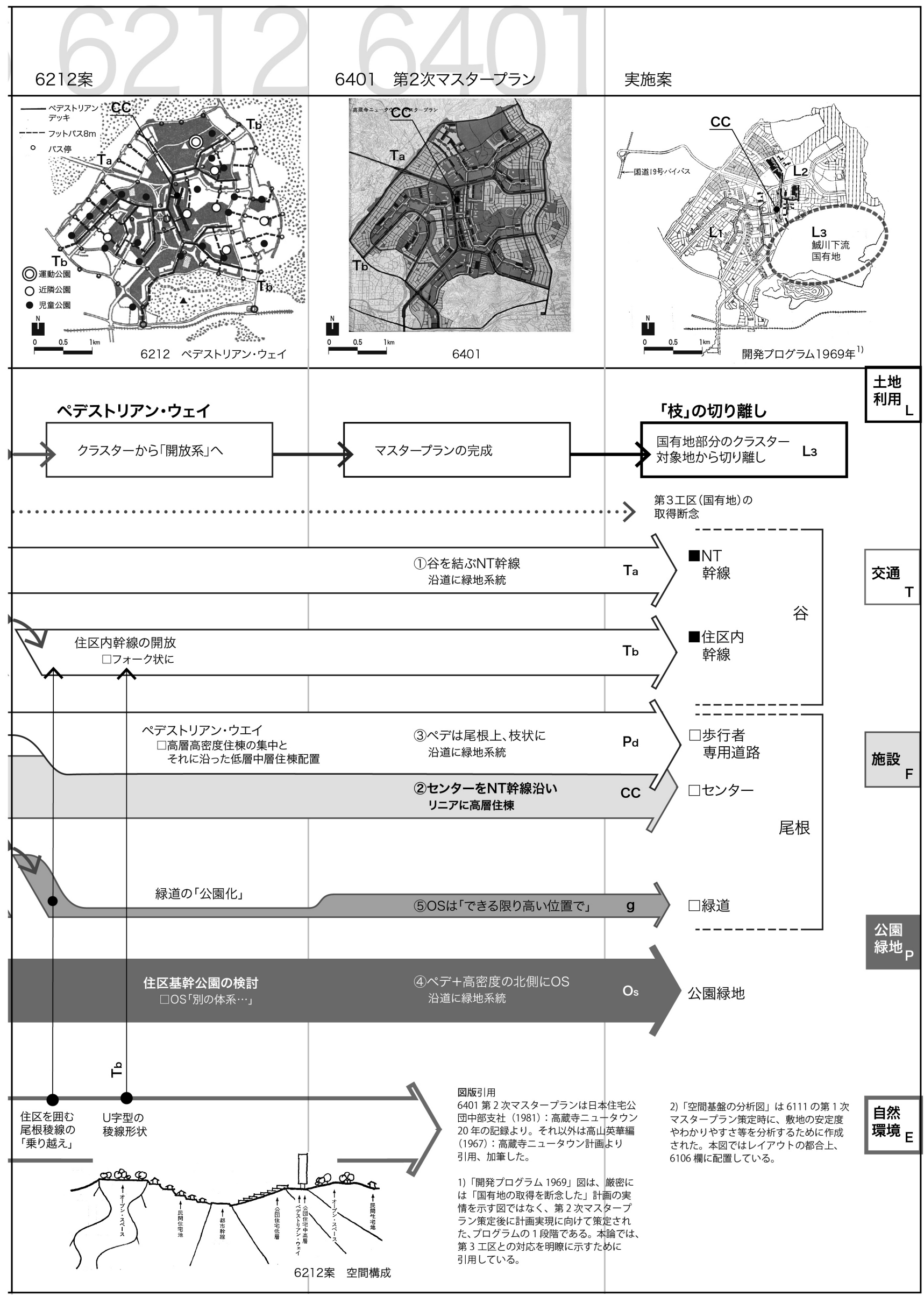


帯が形成された。これは学校や公園緑地をつなぐ歩行者専用空間 で，センターから放射状に延びる機能の軸と並ぶ歩行者空間だっ た。かし 6212 案において住区幹線道路が放射状に開放されると ペデストリアン・ウエイが拡充されるのに対し，緑道はその質を 変え, 機能をもつ帯としての緑道は消失する。再び 6401 案で若干 の機能連携が見られるが，住区を囲む尾根軸上の緑道の帯は，放 射型の機能軸に乗り越えられる形で姿を消す。この 6202 案に見ら れる東側尾根筋の帯は, 港北 NT のグリーンマトリックスシステム の萌芽と見なすこともできそうではあるが，その結実には時期尚 早で，立地の地形も，放射状に伸張する機能軸を妨げるほじ急峻 ではなく，環状の機能の帯を維持できるほど明瞭な形状をもって はいなかった。

\section{7. おわりに}

高蔵寺 NT において, 機能の軸を集約し高密高層住棟で尾根筋を 形作る “骨太”の計画が何故実現できたか?その背景には，立地 の自然環境，特に地形が大きく関与していた。

現在, 初期のNT の集合住宅団地では, 老朽化した集合住宅団地 の建替えが共通課題となっている。その再生に際しては，かつて の開発計画が新たな計画の基盤となり，現在の団地の空間構造を 規定していた自然環境が建替えと切り離され遊離してしまわない よう，十分配慮する必要がある。とくに近年，土木技術や機械の 発達とともに一見克服されたかのようにみえる自然環境が「過去 最大」の自然災害として生活圈内で姿を現わしている。例えば, 震災により丘陵地に開発された造成住宅地の切盛境界で被害が発 生し，集中豪雨により盛土部が地滑りするなどの場面を，私たち は目の当たりした。すでに一度開発された NT の人工の土地に再度 手を加える第 2 の開発がはじまっているが，かつての計画を再考 してその意図を継承し，自然環境構造の把握と十分な配慮の元に 技術が適切に用いられる必要がある。また単に専門家に留まらず, 居住する市民に対しても，自然環境と計画に関わる情報が共有さ れなければならない。その意味で, 地域の自然環境構造を現代的 に再生させる計画・デザインの手法が問われているといえるので はないだろうか。

謝辞: 本論を取りまとめるにあたって，元UR，元広島大学教授の 津端修一先生, 大阪府立大学の武田重昭先生に, 多大なご協力を 賜った。ここに記して感謝の意を示す次第である。なお本研究は 科学研究費基盤(C)「ニュータウンに内在する自然環境を継承・再 編するランドスケープ計画モデルの構築に関する研究」(課題番 号 25450511）による研究の成果である。

\section{補注及び引用文献}

1）篠沢健太・宮城俊作・根本哲夫（2008）：千里ニュータウンの公園緑地 内に内在する自然環境の構造とその発現形態 : ランドスケープ研究, 71 (5)，773-778.

2）根本哲夫・宮城俊作・篠沢健太・岩本芙美代（2009）：初期公団住宅の 団地に内在する自然環境の構造とその発現形態 : ランドスケープ研究, $72(5), \quad 809-814$.

3）宮城俊作(1996) : 地域環境構造を内化する集合住宅地のオープンスペー ス計画一多摩ニュータウン・稲城長峰地区のケーススタディー，日本都 市計画学会学術論文集 $31,91-96$.

4）木下剛・宮城俊作（1998）: 港北ニュータウンのオープンスペースシス テム形成過程における公園緑地の位置づけ:ランドスケープ研究 61 (5)， 721-726.

5）篠沢健太・宮城俊作・根本哲夫（2007）：千里ニュータウンにおける集 水域の構造変容と公園緑地系統の関連 : ランドスケープ研究 70 (5), 647-652.
6）城地園子（2010）: 黎明期のニュータウン開発計画における自然環境の 取扱い方一高蔵寺ニュータウンを事例として一: 奈良女子大学大学院人 間文化研究科住環境学専攻修士論文, $184 \mathrm{pp}$.

7）高山英華編（1967）：高蔵寺ニュータウン計画 : 鹿島出版会, 254pp.

8）村田 孝（1966）: 高蔵寺ニュータウンにおける公園緑地の計画 : 造園雑 誌 $30(2), 27-32$.

9）権奇燦・安部大就・増田昇・下村泰彦・山本聡（1994）: 住民意識調查 を通じたニュータウン内の保存緑地が保有する各種の効果に関する研 究: 造園雑誌 57 (5), 187-192.

10）西山康雄・石浦裕治（1989）：高蔵寺ニュータウンの変容一日本型ニュ ータウン像の検討のために一: 日本都市計画学会学術研究論文集 24 . 541-546.

11）山元貴継（2009）: 高蔵寺ニュータウンの開発と地形改変: 都市地理学 4, 51-61.

12) 津端修 (2010) : 高蔵寺ニュータウンから豊かな暮らしの輪をつなぐ： 都市計画 284, 80-85.

13) 日本住宅公団中部支社(1981) :高蔵寺ニュータウン 20 年の記録:361pp. より引用した。

14）東京大学高山研究室・日本住宅公団 (1961)：高蔵寺ニュータウン開発 基本計画 : 119pp.

15）前掲書 7), 46-47.

16) 前掲書 7), p56.

17）前掲書 7), p56.

18）前掲書 7), 46-47.

19）日本住宅公団名古屋支所（1964）: 高蔵寺ニュータウン計画総合調整な らびに基本計画の検討. 63-88.

20）篠沢健太・宮城俊作・根本哲夫 (2006) : 千里丘陵の開発における地形 の取り扱いと自然環境の構造 : ランドスケープ研究69 (5), 817-822.

21）前掲書 7), 69-70.

22）前掲書 5) 